\title{
ONLINE AND DESIGN-BASED LEARNING IN SOPHOMORE ENGINEERING MECHANICS
}

John M. Long, $1,{ }^{*}$ Akif Kaynak,1 Mariana Paulino, 1 \& Siva Chandrasekaran2

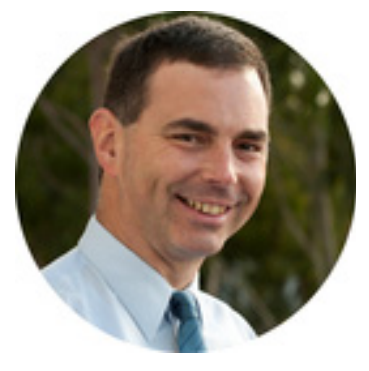

John M. Long

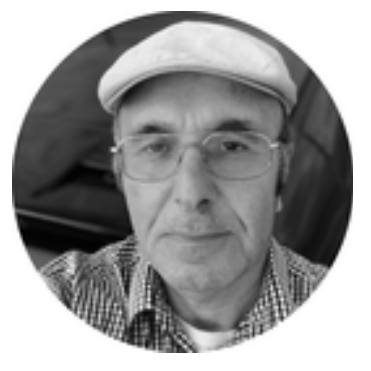

Akif Kaynak

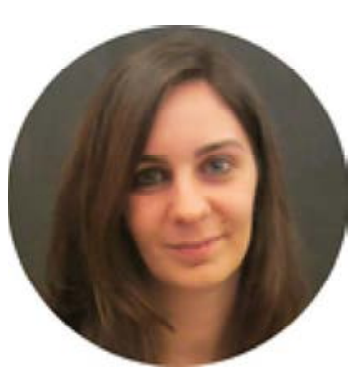

Mariana Paulino

1 School of Engineering, Deakin University, 75 Pigdons Road, Geelong, Victoria 3220, Australia

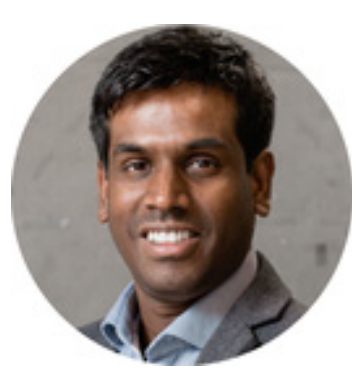

\section{Siva Chandrasekaran}

2 Engineering Practice Academy, Swinburne University of Technology, PO Box 218, Hawthorn, Victoria, 3122, Australia

*Address all correspondence to: John M. Long, School of Engineering, Deakin University, 75 Pigdons Road, Geelong, Victoria 3220, Australia; Tel.: (+61) 35227 2896; Fax: (+61) 35227 2167; E-mail: john.long@deakin.edu.au

\section{Abstract}

For many years, Deakin University in Australia has offered a four-year undergraduate engineering degree program; simultaneously online and on campus. This paper describes how we have applied a new design- and project-based pedagogy to a course in sophomore engineering mechanics for civil and mechanical engineers, both online and on campus. Specific challenges included how to deliver educational content and practical 
experiences to the online cohort in statics, dynamics, and mechanics of materials, setting semester-long design projects that worked with both cohorts, establishing effective communication and interaction between both lecturers and students and among all the students themselves, and assessing learning in both cohorts. By means of modern communication and educational technologies, we did overcome these difficulties. As measured by assignments, lab reports, and exams, the online cohort's mean academic performance was higher than that of the on-campus cohort, as were the mean relative measures of student satisfaction. Our results show that, not only can engineering mechanics be effectively taught simultaneously to on-campus and online students, but the more difficult task of effectively adding a major design element and group work to the program is also achievable.

KEY WORDS: engineering, mechanics, distance learning engineering, on campus versus online

\section{INTRODUCTION}

Since the turn of the century, engineering education has followed two very significant trends. The first is the rise of online learning (Bourne et al., 2005), especially at the master's level (Whiteman, 2012), and to a lesser extent, at the engineering-technology level (ABET, 2018). Numerous educators now offer individual engineering courses online, and some North American universities are now offering engineering bachelor's degree programs either via distance education or online (examples include, Krute et al., 2012; Phillips and Saraniti, 2016; Scott et al., 2012; Tang et al., 2015). The second trend is the shift in educational emphasis from the science of engineering to the practice of engineering through design projects (Froyd et al., 2012). Design is especially seen at this time, 2019, as what distinguishes engineering from other fields of applied science.

For many years, Deakin University in Australia has offered a number of fully accredited Bachelor of Engineering programs online and by distance education, in parallel with more traditional on-campus programs in the same disciplines (Long and Baskaran, 2004; Long et al., 2014a). The educational outcomes of the two modes of delivery are identical, and there is no distinction between an on-campus and an online degree. The two methods of delivery are part of the same degree program. The program seeks to address the need for engineers in Australia and the needs of students who either work or live in remote parts of the continent or who are unable to attend on-campus classes due to work or family commitments. Currently, Deakin offers engineering programs in civil, mechanical, electrical, mechatronics, and environmental. 
Design and projects—central to the training of any engineer-have always been important components in our majors. Until recently, design projects made up $\sim 25 \%$ of the courses in the various programs and always ran both on campus and online. This is especially evident in the mechatronics major (Chandrasekaran et al., 2015; Joordens and Jones, 1998). The past five years have seen the complete redevelopment of Deakin's undergraduate engineering curricula to shift the emphasis from the more traditional engineering degree to one that explicitly emphasizes design projects and collaborative learning.

The new pedagogy is called project-oriented design-based learning (PODBL) and is the result of several years' research, wide consultation with industry and student groups, and pilot trials in individual courses (Chandran et al., 2015; Chandrasekaran et al., 2012, 2013, 2014). PODBL is an approach to teaching and learning that is based on engineering design activities while driven by a project. PODBL encourages independent, deep learning for students. It is also an approach that supports the development of information literacy and design thinking in the field of tertiary education-two key learning outcomes in engineering. The approach is a unique combination of the two, which incorporates creativity and innovation aspects in projects practiced through design activities. It focuses on students learning through real design activities while driven by a project that has defined deliverable outcomes that are assessed by academics at the end of each semester.

In a studio-based learning environment, participants work in teams of four to six members with a facilitator. The facilitation happens in a way that the problem or project is given in the first week of semester, where students identify the problem, brainstorm and identify the gaps in their knowledge, and identify the learning approach toward a solution. The same team meets regularly throughout the semester to work on a series of design activities. When the team meets the facilitator in week 3 or 4 , depending on the speed of team progression in working out the possibilities, the facilitator guides the team to the next stage of choosing their solution to design, prototype, and iterate with alterations and testing.

The learning and teaching delivery is a combination of online and on-campus learning activities (Chandran et al., 2013). Collaborative learning enables students to evidence their achievement while they are learning through a studio-based learning environment. The subject content is covered in integrated short, accessible, highly visual, media-rich, interactive learning experiences built for the mobile screen, and integrating learning resources created by the university. Studio-based learning requires students to be generators of content, collaborators in solving real-world problems, and presenters of their achievements in professional and personal digital portfolios. With premium cloud-learning experiences in place, students who come to campus have the opportunity to engage with 
the teaching staff and peers in opportunities for rich interpersonal interaction through large and small team activities.

PODBL is an opportunity for the students to experience a self-directed learning experience with an appropriate amount of facilitation. The amount of facilitation and support is more in the freshman year and gradually goes down from sophomore year to senior year. On the opposite side, the students' capability of taking ownership of their learning increases from freshman year toward the final year of learning progress. It needs continuous professional development for both students and academics who are involved in learning and teaching. From previous experience from problem-, project-, and design-based learning approaches around the world, PODBL is a combination of the problem-, project-, and design-based learning components. PODBL caters to online engineering students as well as traditional on-campus students (Maung-Than-Oo et al., 2014).

The first freshman year in the PODBL curriculum started in first semester, 2016. Sophomore year also started at the same time. The third year of implementation was in the first semester of 2018. All four years of the civil, electrical, mechanical, and mechatronics engineering programs have now been taught by PODBL. Table 1 shows the course structure for the Bachelor of Engineering Mechanical in the new curriculum. Each individual course has a credit-point (cp) value. A one-credit-point course involves $\sim 150 \mathrm{~h}$ of class work and private study. A standard academic year is eight credit points of course work, for a total of 32 credit points in the entire four-year program. A hallmark of the PODBL pedagogy is that one-half of all course work is in the form of design projects. The remaining courses serve to teach fundamental physics, computing, mathematics, and engineering principles such as fluid mechanics, thermodynamics, and mechanics of materials.

Previously, we presented preliminary reports on the implementation of PODBL in the courses Engineering Physics (Long et al., 2016) and Machine Design (Long et al., 2017). In this paper, we consider how the implementation went in the sophomore course SEJ201, Structural Design. This course focuses on the students' first training in engineering mechanics. We briefly describe the course that proceeded SEJ201 in the old structure. We present the curriculum of the new two-cp course. We then consider both the academic performance and satisfaction of the sophomore mechanical students before and after the change. Finally, we consider the lessons learned from the experience as they relate to online cohorts.

\section{PRE-2016}

Prior to the 2016 rollout of PODBL, the second year of both the mechanical and civil majors contained two traditional single-cp courses dedicated to mechanics: SEM223, 
TABLE 1: PODBL course structure for Bachelor of Engineering Mechanical

\begin{tabular}{|c|c|c|c|}
\hline \multicolumn{4}{|c|}{ Freshman Year } \\
\hline Sem-1 & $\begin{array}{c}\text { SEJ101 } \\
\text { Design Fundamentals (2 } \\
\text { cp PODBL) }\end{array}$ & $\begin{array}{c}\text { SIT199 } \\
\text { Applied Algebra and } \\
\text { Statistics }\end{array}$ & $\begin{array}{c}\text { SEB101 } \\
\text { Engineering Physics }\end{array}$ \\
\hline Sem-2 & $\begin{array}{l}\text { SEJ103 } \\
\text { Materials Engineering } \\
\text { Project (2 cp PODBL) }\end{array}$ & $\begin{array}{l}\text { SIT172 } \\
\text { Programming for } \\
\text { Engineers }\end{array}$ & $\begin{array}{c}\text { SIT194 } \\
\text { Introduction to } \\
\text { Mathematical Modeling }\end{array}$ \\
\hline \multicolumn{4}{|c|}{ Sophomore Year } \\
\hline Sem-1 & $\begin{array}{c}\text { SEM200 } \\
\text { Machine Design (2 cp } \\
\text { PODBL) }\end{array}$ & $\begin{array}{c}\text { SEP291 } \\
\text { Engineering Modeling }\end{array}$ & $\begin{array}{l}\text { SEM218 } \\
\text { Fluid Mechanics }\end{array}$ \\
\hline Sem-2 & $\begin{array}{c}\text { SEJ201 } \\
\text { Structural Design (2 cp } \\
\text { PODBL) }\end{array}$ & $\begin{array}{c}\text { SEM216 } \\
\text { Stress and Failure } \\
\text { Analysis }\end{array}$ & $\begin{array}{c}\text { SEM202 } \\
\text { Thermodynamics }\end{array}$ \\
\hline \multicolumn{4}{|c|}{ Junior Year } \\
\hline Sem-1 & $\begin{array}{c}\text { SEM300 } \\
\text { Thermo-Fluid System } \\
\text { Design ( } 2 \text { cp PODBL) }\end{array}$ & $\begin{array}{c}\text { SEM313 } \\
\text { Manufacturing }\end{array}$ & $\begin{array}{c}\text { SED304 } \\
\text { Product Development }\end{array}$ \\
\hline Sem-2 & $\begin{array}{c}\text { SEM301 } \\
\text { Industrial Control (2 cp } \\
\text { PODBL) }\end{array}$ & $\begin{array}{c}\text { SEM327 } \\
\text { Dynamics of Machines }\end{array}$ & $\begin{array}{c}\text { SEM302 } \\
\text { Advanced Stress Analysis }\end{array}$ \\
\hline \multicolumn{4}{|c|}{ Senior Year } \\
\hline Sem-1 & $\begin{array}{c}\text { SEJ441 } \\
\text { Capstone Project } 1 \text { (2 cp) }\end{array}$ & $\begin{array}{c}\text { SEM400 } \\
\text { Computational Fluid } \\
\text { Dynamics }\end{array}$ & elective \\
\hline Sem-2 & $\begin{array}{c}\text { SEJ446 } \\
\text { Capstone Project (2 cp) }\end{array}$ & $\begin{array}{c}\text { SEM406 } \\
\text { Advanced Modeling } \\
\text { and Simulation }\end{array}$ & elective \\
\hline
\end{tabular}

Statics and Dymanics, and SEM222, Stress Analysis (Hall et al., 2007). Both courses ran for several years, both on campus and online. On-campus class time was divided up into lectures, tutorials, and lab classes. Online students accessed learning resources and lecture recordings by means of the course website and the university learningmanagement system. Online students also participated in weekly online tutorials by means 
of the web-conferencing software Elluminate Live (Long et al., 2014b). Table 2 lists the content and assessment details for these two courses. These two courses also ran in 2016 to allow some students who enrolled prior to 2015 to complete their degrees in the old structure.

TABLE 2: Pre-2016 sophomore mechanics courses

\begin{tabular}{|ccc|}
\hline Code & SEM223 & SEM222 \\
Title & Engineering Mechanics & Stress Analysis \\
Semester & $1(11$ weeks) & $2(11$ weeks) \\
Content & Statics 60\% and dynamics 40\% & $\begin{array}{c}\text { Stress and strain, mechanical } \\
\text { loading, mechanical properties of } \\
\text { materials, bending, torsion, } \\
\text { elastoplastic behavior of materials, } \\
\text { shear }\end{array}$ \\
Assessment & $\begin{array}{c}\text { Exam 60\%, assignments 20\%, lab } \\
20 \%\end{array}$ & $\begin{array}{c}\text { Exam } 60 \% \text {, assignments 20\%, lab } \\
20 \%\end{array}$ \\
Textbook & $\begin{array}{c}\text { Hibbeler, Statics (Hibbeler, 2012b); } \\
\text { Dynamics (Hibbeler, 2012a) }\end{array}$ & $\begin{array}{c}\text { Hibbeler, Mechanics of Materials } \\
\text { (Hibbeler, 2013) }\end{array}$ \\
\hline
\end{tabular}

\section{SEJ201 STRUCTURAL DESIGN}

In the new degree program, SEM222 and SEM223 were discontinued. The content of SEM222 went to a new unit, SEM216, Stress and Failure Analysis. SEM223 was replaced by a new double-cp course, SEJ201, Structural Design. SEJ201 introduces and explores the fundamental concepts of mechanics of structures most relevant to civil and mechanical students. The theory part of the unit is essentially a course on statics and mechanics of materials. It builds on concepts introduced in freshman physics and materials, presents all the essential modules of statics, and continues with topics on deformable body mechanics, such as stress, strain, mechanical properties, pure bending in beams, and torsion in shafts. That is, all of the statics components of SEM223 went into SEJ201, and some aspects of mechanics of materials were also added. In addition to the major project, the laboratory work on shear and bending moment diagrams, internal forces, calculations of section properties, stresses in beams, analysis of forces in a truss, and a suspensionbridge experiment of SEM223, Statics and Dynamics, were retained. The new course addresses skills applied in the context of a real-world structural design project. It is a core course in both the mechanical and civil majors.

SEJ201 has six learning outcomes. Students who complete the course can: 
1. Apply structural engineering fundamental knowledge in conjunction with appropriate tools and resources to analyze and design elements to satisfy user requirements

2. Apply specialized structural knowledge, technical competence, and open-ended problem-solving skills in finding appropriate, creative, and/or innovative engineering solutions

3. Identify and characterize important issues, justify and apply appropriate simplifying assumptions, and propose substantiated solutions

4. Collaborate with others as an effective member of an engineering team and reflect on development of team skills

5. Apply knowledge of the health and safety responsibilities of the professional engineer, including integration of the principles of safety engineering, occupational health-andsafety (OHS), and legal requirements

6. Communicate project outcomes, through the use of oral, written, and graphical communication to professional and nonprofessional audiences

The student assessment is a mixture of team and individual items:

- Three individual online tests $20 \%$

- Team project design brief $20 \%$

- Individual interim report responding to a mid-project "change" in design requirements $20 \%$

- Individual final report $40 \%$

The assessment methods, rubrics, and online tests were identical both for on-campus and online cohorts. To ensure that students adequately learned the theoretical aspects of mechanics, they were required to obtain at least $50 \%$ of the marks allocated in the online tests to pass the course, irrespective of their performance in the project components. The textbook for the course was Hibbeler's Statics and Mechanics of Materials (Hibbeler, 2014). The project involved designing the principle structural components of a pedestrian bridge. At the beginning of the semester, students were provided with a "basis-of-design brief," containing the key engineering specifications and a set of technical drawings from a preliminary design stage. Students placed themselves in teams of four to six, including a minimum of two civil engineering students and a minimum of two mechanical engineering students so they would work in multidisciplinary teams.

The design component was for a single-span foot bridge. Figure 1 shows the bridge used as a model for 2016 and 2017. It provides a safe shared-use path for pedestrians and 
cyclists over a local creek. Students were responsible for performing the necessary analysis and providing a preliminary design solution report for costing, as well as a Safetyin-Design risk assessment as a final project report, compliant with the relevant Australian engineering standards.

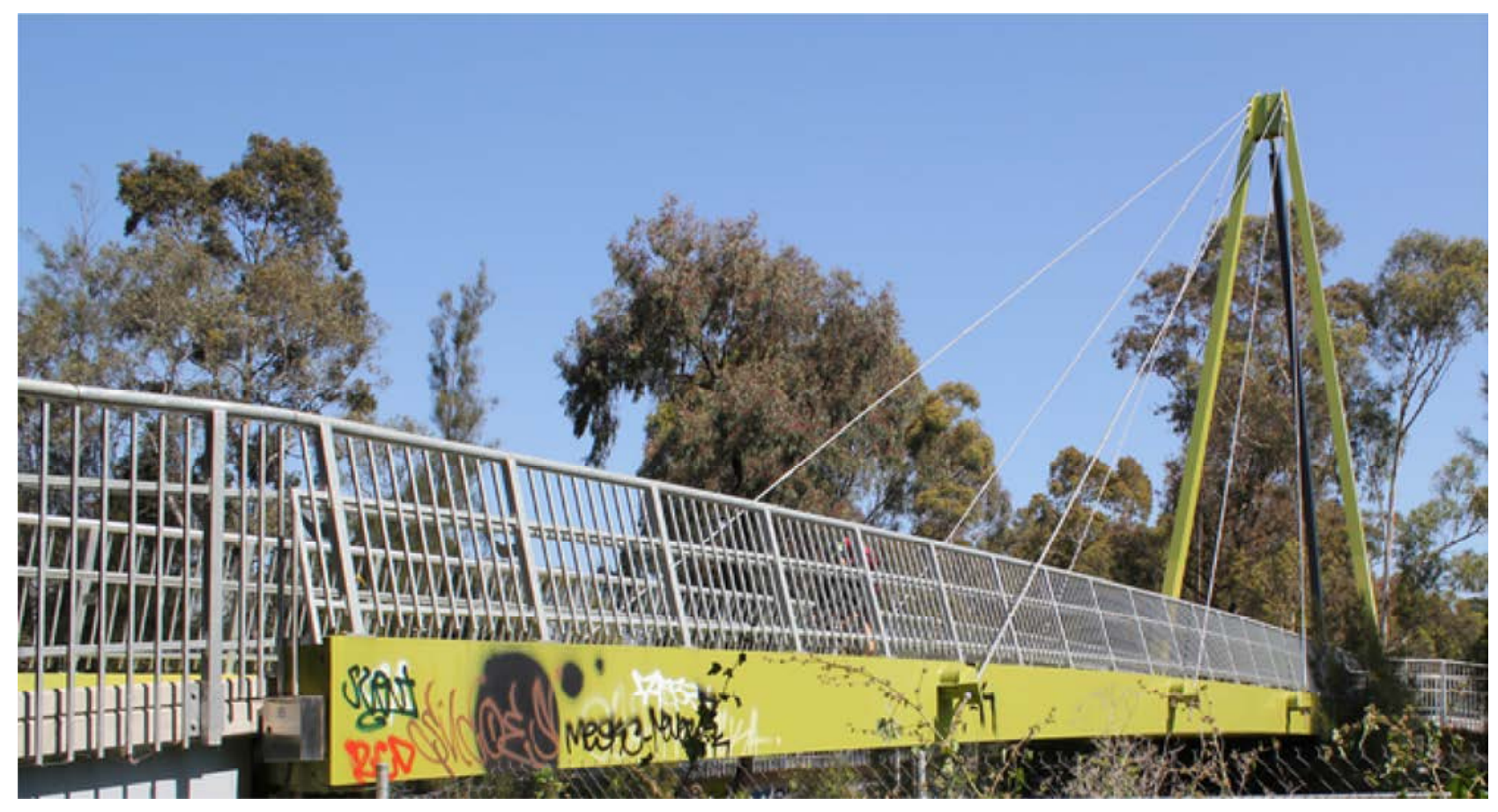

FIG. 1: Pedestrian bridge used as a model for the design project

At the end of the semester, the students were expected to submit an individual report that included a brief introduction of the project and major constraints of the design project. Students were also required to include in their final report analyses and designs for a number of diverse structural elements, including stay-cables, backstay, A-frame tower, longitudinal and transverse beams, and foundations. This allowed them to apply the acquired knowledge for structure under various loading conditions, as well as apply different methods used in mechanics of structures.

During the 11-week semester, weekly on-campus class time was divided into $2 \mathrm{~h}$ of lecture, $2 \mathrm{~h}$ of seminars, two separate $2 \mathrm{~h}$ design studios, and two lab sessions of $2 \mathrm{~h}$ each. Seminars were similar to tutorials in that the class was divided into small groups for problem-solving and collaborative group work. Lectures and seminars were used to deliver the primary educational content; most of this content was concepts from the Hibbeler (2014) text and associated mechanics problems. The two studios had separate roles. The first studio focused on the analysis and design of the bridge and its structural members, and it gave students the opportunity to work in their teams. In the second studio session, 
civil and mechanical students were assigned to different groups and instructed on discipline-specific design tools, standards, and professional practice. Table 3 shows the topics covered and class activities, week by week.

TABLE 3: Weekly class topics and activities

\begin{tabular}{|c|c|c|}
\hline Week & Class, Seminar, and Project Studio Topic & Discipline Studio Topic \\
\hline 1 & $\begin{array}{c}\text { Introduction and revision: Forces, moment of a } \\
\text { force in two and three dimensions, vector } \\
\text { operations }\end{array}$ & $\begin{array}{l}\text { Introduction to design project: } \\
\text { Drawings }\end{array}$ \\
\hline 2 & $\begin{array}{c}\text { 2D equilibrium and support reactions, introduction } \\
\text { to trusses }\end{array}$ & $\begin{array}{c}\text { Professional practice: Team } \\
\text { charter }\end{array}$ \\
\hline 3 & $\begin{array}{c}\text { Detailed truss force analysis, frames, and internal } \\
\text { forces }\end{array}$ & Industry Q \& A \\
\hline 4 & $\begin{array}{l}\text { Axial loading and Poisson's ratio, stress and } \\
\text { strain, Hooke's Law and elastic constants, } \\
\text { mechanical properties of materials }\end{array}$ & $\begin{array}{l}\text { Professional practice: } \\
\text { Occupational health and } \\
\text { safety in design }\end{array}$ \\
\hline 5 & $\begin{array}{l}\text { Shear and bending-moment diagrams, } \\
\text { relationship between transverse loading, shear } \\
\text { and moment, bending }\end{array}$ & Analysis software session 1 \\
\hline 6 & Centroids, moments of inertia for areas & Analysis software session 2 \\
\hline 7 & \multicolumn{2}{|c|}{ INTENSIVE WEEK ACTIVITIES } \\
\hline 8 & $\begin{array}{l}\text { Pure bending (elastic flexure formulas) and } \\
\text { transverse shear stress in beams }\end{array}$ & Analysis software session 3 \\
\hline 9 & Review & Industry $Q$ \& $A$ \\
\hline 10 & Project focus & Project focus \\
\hline 11 & Project focus & Project focus \\
\hline
\end{tabular}

All lectures, seminars, and studios were video-recorded, and the recordings were posted to the course website. Although this was done mainly for the online cohort, the on-campus cohort also had access to the recordings and viewed them regularly. The teaching team held twice-weekly online seminars for the online students by means of the webconferencing software BlackBoard Collaborate (Fig. 2). Each week both online seminars were recorded and made available to all students. The first seminar was to review and practice mechanics problems. The second seminar was to help online students with their projects. 


\section{Loads \& Load Factors}

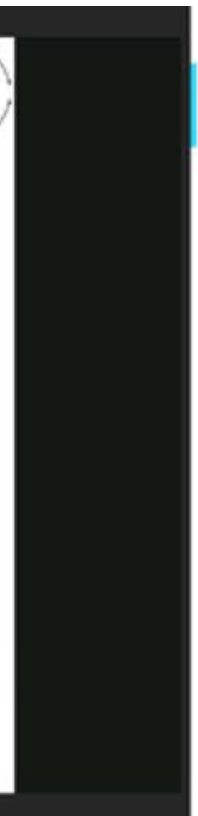

Chat

yos

asdent

ys

Load Application in Structural Analysis

- Determine WHICH loads are applied

suserst

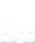

studert 1

was confured about how many FBD wees

wequind lor the crossberms

- Loads types (dead, live, environmental)

- Estimate magnitude of each load

- Determine HOW load is applied

- P: Concentrated/Point load [kN]

- Distributed Load (UDL):

w: Line Load [kN/m]

q: Area Load $\left[\mathrm{kN} / \mathrm{m}^{2}\right]$

- Determine WHERE loads are applied.

- Location and extent

thesect 1

(1)er anch lasd combination then another 3 lor the

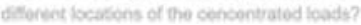

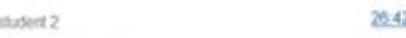

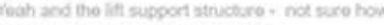

mary we nowd lo do there as WEL.

towort3 3

How is the cancey load diatreuted? Destbuted ce

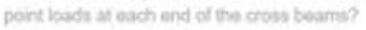

susent 4

FIG. 2: Screenshot of a segment of an online tutorial via the BlackBoard Collaborate webconferencing software. The presentation is on the left, and student comments are on the right.

The students also had access to the Pearson's Mastering Engineering e-learning package, which includes interactive problems (Pearson Education, 2018). Deakin University in collaboration with Pearson incorporated the access to Mastering Engineering into the course website, which provided students with free access. Students who utilized the website found it very beneficial as they gained experience by solving relevant interactive problems. Moreover, pre-recorded topical videos were also uploaded to the course website as extra resources. This was particularly helpful for off-campus students, some of whom were motivated to study the topics in advance.

In week 7, online students attended a two-day intensive experience at the home campus with the on-campus cohort. During this intensive week, all students attended a one-day workshop facilitated by the teaching team and an industry collaborator. Here, two new project constraints were presented. Then the impact and consequences of the new constraints on the project analysis and design tasks were discussed by the students in their teams. This exposed the students to the common case of when the client changes the specifications of a project halfway through the design process. On the second day, online students attended lab practical sessions on engineering mechanics. In separate sessions at other times in the semester, on-campus students completed the same lab activities. It was also during the intensive week that the online students had the opportunity to attend in-person software troubleshooting sessions with the teaching team. 


\section{METHODOLOGY}

In this study, we examine student enrolments and completions, academic performance, and student satisfaction for the three years, 2016-2018. For comparison, we also include the academic performance of SEM223 for 2015 and 2016. We measured student satisfaction by means of a university standard survey of students who complete the course (Palmer, 2012). In this survey, 11 statements are posed and students indicate their agreement or disagreement on a Likert scale (Table 4). The students are also invited to make comments on aspects of the unit with which they are happy and those aspects that require improvement.

TABLE 4: Survey questions on student satisfaction

\begin{tabular}{|cr|}
\hline $\begin{array}{c}\text { No. } \\
1\end{array}$ & Survey Statement \\
2 & The learning experiences in this course help me to achieve the learning outcomes. \\
3 & The learning resources in this course help me to achieve the learning outcomes. \\
4 & The assessment tasks in this course evaluate my achievement of the learning \\
5 & Feedback on my work in this course helps me to achieve the learning outcomes. \\
6 & The workload in this course is appropriate to the achievement of the learning \\
7 & The quality of teaching in this course helps me to achieve the learning outcomes. \\
8 & I am motivated to achieve the learning outcomes in this course. \\
9 & I make best use of the learning experiences in this course. \\
10 & I think about how I can learn more effectively in this course. \\
11 & Overall, I am satisfied with this course.
\end{tabular}

\section{RESULTS}

Over the three years, 2016-2018, a total of 328 on-campus and 58 online students completed the course. Of the online students, 22 lived within a $2 \mathrm{~h}$ drive of the home campus (Geelong and Melbourne). Two students lived in rural Victoria, and 34 lived in other states (including four from Western Australia). The average on-campus student was 22 years old; whereas, the online students were, on average, 30 years old.

Table 5 shows the final academic results for SEJ201. The minimum grade required to pass the course was $50 \%$. For some comparison, academic results for the earlier course 
SEM223 are shown in Table 6. In SEJ201, the academic grades for online students were higher (seven percentage points, on average) than those of the on-campus students; whereas for SEM223, the grades of online students were about the same as those of the on-campus students (only one percentage point difference). For SEJ201, grades improved for both cohorts in the second year of offer but decreased in the third year. Although a direct comparison between the two courses is not apples-to-apples, it is important to consider whether, in the case here of mechanics, a very significant change in curriculum and pedagogy resulted in a massive change in grades, up or down. In this case, average grades did not go down after the change. The difference between the academic performances of the two courses was possibly reduced due to having a hurdle requirement in the compulsory online quizzes. Although the percentage contribution of these to the overall result was low, we believe that the hurdle was effective in motivating students to attend lectures and tutorials, and regularly practice solving Mastering-Engineering interactive questions. It was observed that attendance at online classes was quite high as compared to corresponding classes in other courses. This might be attributed to

TABLE 5: Academic results for SEJ201 2016-2018

\begin{tabular}{|ccccccc|}
\hline Year & Cohort & $\begin{array}{c}\text { No. of } \\
\text { Students } \\
\text { Completed }\end{array}$ & $\begin{array}{c}\text { No. of } \\
\text { Students } \\
\text { Withdrawn }\end{array}$ & $\begin{array}{c}\text { Average } \\
\text { Final } \\
\text { Grade/100 }\end{array}$ & $\begin{array}{c}\text { Standard } \\
\text { Deviation }\end{array}$ & $\begin{array}{c}\text { Median } \\
\text { Final } \\
\text { Grade/100 }\end{array}$ \\
2016 & On campus & 95 & $4(4 \%)$ & 60 & 18 & 61 \\
2017 & On campus & 115 & $17(13 \%)$ & 63 & 12 & 65 \\
2018 & On campus & 118 & $10(8 \%)$ & 60 & 14 & 63 \\
2016 & Online & 8 & $6(43 \%)$ & 64 & 14 & 66 \\
2017 & Online & 22 & $6(21 \%)$ & 73 & 12 & 74 \\
2018 & Online & 28 & $8(22 \%)$ & 66 & 18 & 71 \\
\hline
\end{tabular}

TABLE 6: Academic results for SEM223 2015-2016

\begin{tabular}{|ccccccc|}
\hline Year & Cohort & $\begin{array}{c}\text { No. of } \\
\text { Students } \\
\text { Completed }\end{array}$ & $\begin{array}{c}\text { No. of } \\
\text { Students } \\
\text { Withdrawn }\end{array}$ & $\begin{array}{c}\text { Average } \\
\text { Final } \\
\text { Grade/100 }\end{array}$ & $\begin{array}{c}\text { Standard } \\
\text { Deviation }\end{array}$ & $\begin{array}{c}\text { Median } \\
\text { Final } \\
\text { Grade/100 }\end{array}$ \\
2015 & On campus & 138 & $13(9 \%)$ & 61 & 20 & 61 \\
2016 & On campus & 48 & $9(16 \%)$ & 57 & 16 & 60 \\
2015 & Online & 45 & $9(17 \%)$ & 60 & 25 & 60 \\
2016 & Online & 39 & $9(19 \%)$ & 56 & 20 & 57 \\
\hline
\end{tabular}


compulsory tests, student enthusiasm, or the skills of the teaching team. Keeping up with the theoretical aspects of the course helped students tackle the laboratory and project work more effectively.

The data also show that the online cohort has a higher dropout rate than the on-campus cohort. Of the total number of students who enrolled, nine percent of on-campus students withdrew from the course as opposed to $26 \%$ of online students who withdrew. This is consistent with other studies, which show that attrition is a serious issue in online courses (Carr, 2000; Moody, 2004; The New York Times, 2013). It is also consistent with an earlier study of attrition in Deakin University engineering courses, where it was found that the withdrawal rate for off-campus students ranged between 25 and $50 \%$, and the percentage of students withdrawing was significantly higher than that for on-campus students (Palmer and Bray, 2002). This previous work suggests that competing pressures on the typical online student, such as balancing employment, family, finances, and study, are the biggest factors in why the attrition in online engineering courses is so high. This explanation is certainly concordant with the authors' direct observations in teaching online engineering courses.

Figure 3 shows the results of the student-satisfaction surveys 2016-2018, and Table 7 shows how many students in each cohort responded to the survey each year. In all categories except two, online-student satisfaction was higher than on-campus and, in most cases, equal or higher than the university average. All students appreciated the "realengineering" nature of the course. Online students appreciated the recordings of all classes and seminars. The lowest scoring survey item for online students was question 6 , workload being appropriate. As one would expect, all students who answered the survey seemed to think that the course was hard work, as compared to other courses. The online students would be acutely aware of this, because they have the added pressures of fulltime work and family, which most of the younger, on-campus students do not have. 


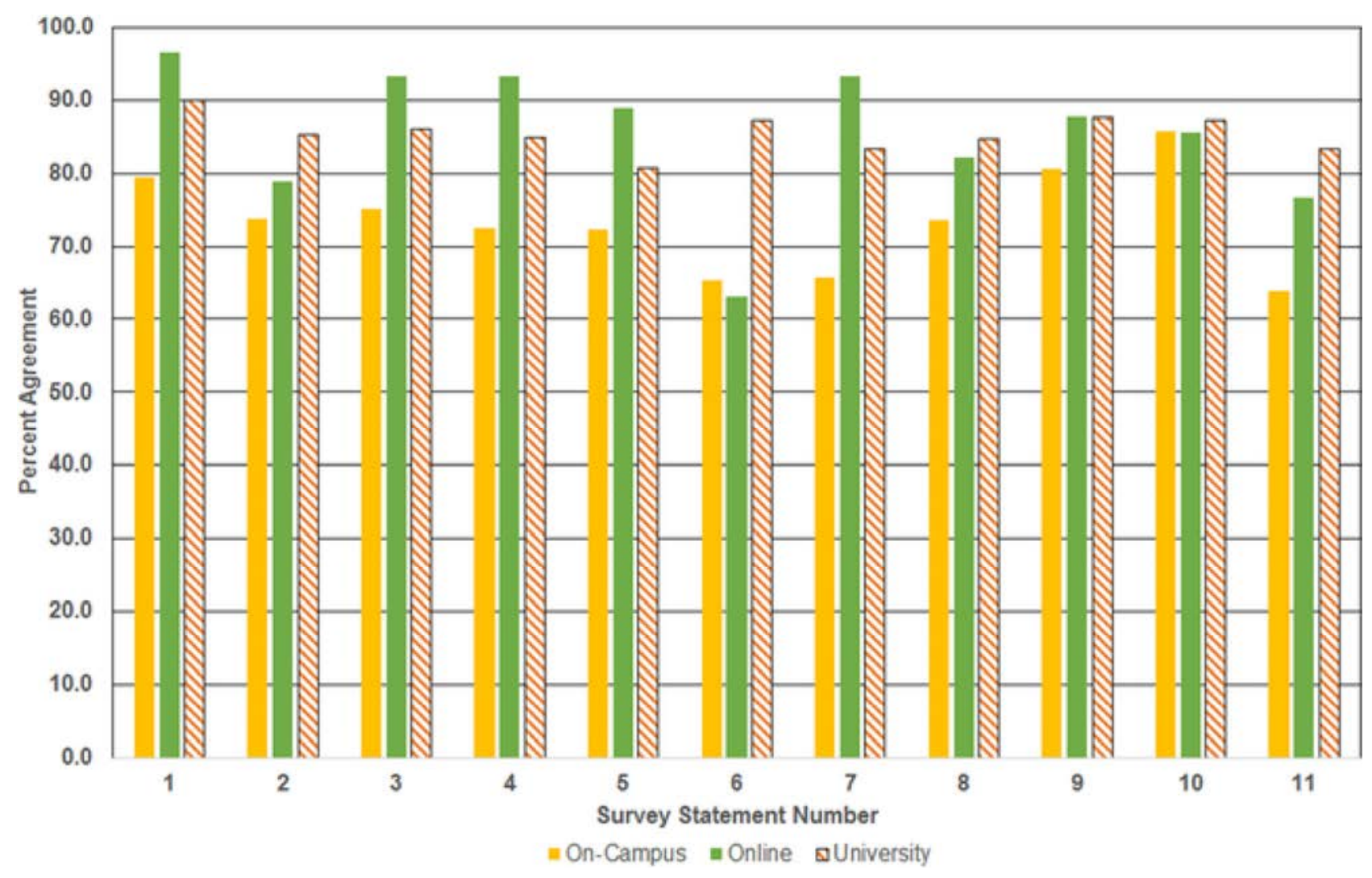

FIG. 3: Student satisfaction results for SEJ201, 2016-2018

TABLE 7: Number of students who answered the coursesatisfaction survey

\begin{tabular}{|cccc|}
\hline & \multicolumn{4}{c|}{ No. of Students } & \multicolumn{3}{c|}{ Completing the Survey } \\
& 2016 & 2017 & 2018 \\
On-Campus & 35 & 29 & 30 \\
Online & 3 & 6 & 11 \\
\hline
\end{tabular}

\section{DISCUSSION}

PODBL has completed its third year of implementation. One can study the academic and student-satisfaction results of this course with two other courses that have been given a similar preliminary analysis. The academic results of SEJ201 are similar to those of another PODBL course being taught in the mechatronics and mechanical majors, SEM200, Machine Design (Long et al., 2017). Like SEJ201, for both 2016 and 2017, online students in SEM200 on average outperformed the on-campus students, with grades being in $65-75 \%$ range. Although not identical, student-satisfaction scores for SEM200 were comparable to those in SEJ201. Looking at survey question 11, overall satisfaction 
with the course, online students in SEJ201 were, in general, slightly less satisfied with their course than were the online SEM200 students. However, the overall satisfaction of both courses was over $80 \%$ for online students. Overall satisfaction among the on-campus students was generally lower than for the online students. This is not surprising because online students tend to be more mature than the on-campus students. Most online engineering students have full-time jobs. Many already work in industry and have experience with project and design work in their professions.

In contrast, in the fundamental unit SEB101, Engineering Physics (Long et al., 2016), a preliminary analysis for 2016 showed that the median academic performance for online students was quite close to that for the on-campus students. In this course, overall student satisfaction was lower for online students than for on-campus students. In physics, we suspect that on-campus students have an educational advantage over the online students in that on-campus students, mostly being fresh out of high school, have more recent practice with fundamental problem solving and doing lab experiments than the online students have. Whereas many on-campus students study physics in high school, there are significant numbers of online students who, in SEB101, are taking a formal physics course for the first time, and there are others who are studying physics after a break of several years since high school. A similar pattern can be seen when comparing academic results of SEJ201 with those of SEM223.

From our experience in teaching SEJ201, we note three important lessons regarding online students. Firstly, students generally preferred working in groups with other online students who have similar commitments, namely, working full time, who usually choose to work on their project and assignments during the evening and/or weekends, and who use the same online platforms and tools to collaborate. Secondly, it is very important that every class, presentation, or discussion taking place during on-campus contact sessions are recorded in order for the online students to feel like they are being offered an equivalent learning experience. Recording all audio, including questions posed by students in the classroom and all "whiteboard" workings as they are being presented/written down, were considered essential. (A tablet and document camera were used for this purpose.) This reassures online students that they are not missing out on any information by studying remotely and in their own time. Thirdly, allowing students some time (four to six days) to watch the recordings and following up with online question-and-answer sessions seemed to be well received, with at least $30-40 \%$ of the students regularly attending those sessions. Even though these sessions were also recorded and uploaded to the unit website, students found that attending the live sessions added significant value to their learning experience, even when the students did not have their own questions to ask. 
Some teaching staff noted with concern that the new course does not place as much emphasis on rigorous learning of engineering mechanics, especially since the assessment in mechanics concepts and problem solving has been changed from an examination to online quizzes. On the other hand, the point of changing the curriculum of the entire program was to make it more exemplary of real engineering-what engineers actually do: designing solutions to real-word problems through projects. The educator faces this tradeoff in shifting emphasis from the science and analysis of engineering to the practice of engineering. It will take several more years of experience from the teachers and their graduates to decide whether going the way of project- and design-based learning was a good idea or not. At this early stage, while acknowledging the program's limitations, we can say, "So far so good."

\section{CONCLUSIONS}

In response to recent trends in engineering education, Deakin University in Australia has shifted emphasis in engineering pedagogy from the more traditional approach of fundamentals first, then design projects, to design- and project-based learning from the start and throughout the entire program. This is being applied to all baccalaureate engineering majors and is taken by both on-campus and online cohorts. Called projectoriented design-based learning (PODBL), the teaching approach recently finished its third year of implementation. In a sophomore-year engineering mechanics course taught by the PODBL method, online students tended to outperform their on-campus counterparts in academic performance. Academic performance of both cohorts was not hugely different from that in similar courses in the previous curriculum and in comparison to other new PODBL courses. Online students tended to be more satisfied with the course than the oncampus students, perhaps in part due to online students generally having more experience with professional projects than the younger and less experienced on-campus students.

\section{REFERENCES}

ABET, Online Programs, Accreditation Board for Engineering and Technology, accessed November 30, 2018, from https://www.abet.org/accreditation/find-programs/, 2018.

Bourne, J., Harris, D., and Mayadas, F., Online Engineering Education: Learning Anywhere, Anytime, J. Eng. Educ., vol. 94, no. 1, pp. 131-146, 2005.

Carr, S., As Distance Education Comes of Age, the Challenge is Keeping the Students, Chronicle Higher Educ., vol. 46, no. 23, pp. A39-A41, 2000.

Chandran, J., Chandrasekaran, S., and Stojcevski, A., A Project/Design Approach to Electrical Engineering, K. Hawwash and C. Léger, (eds.), SEFI 2015: Diversity in 
Engineering Education: An Opportunity to Face the new Trends of Engineering, European Society for Engineering Education (SEFI), Brussels, Paper No. 56735, 2015.

Chandran, J., Chandrasekaran, S., and Stojcevski, A., Integration of Cloud Based Learning in Project Oriented Design Based Learning, Mohd-Yusof, K., Arsat, M., Borhan, M.T., Graff, E.D., Kolmos, A., and Phang, F.A. (eds.), PBL Across Cultures: Proc. of 4th Int. Research Symp. on Problem-Based Learning, Aalborg University Press, Aalborg, Denmark, pp. 358-363, 2013.

Chandrasekaran, S., Stojcevski, A., Littlefair, G., and Joordens, M., Project-Oriented Design-Based Learning: Aligning Students' Views with Industry Needs, Int. J. Eng. Educ., vol. 29, no. 5, pp. 1109-1118, 2013.

Chandrasekaran, S., Littlefair, G., Joordens, M., and Stojcevski, A., Cloud-Linked and Campus-Linked Students' Perceptions of Collaborative Learning and Design Based Learning in Engineering, Int. J. Digital Info. Wireless Commun., vol. 4, no. 3, pp. 267-275, 2014.

Chandrasekaran, S., Long, J.M., and Joordens, M.A., Evaluation of Student Learning Outcomes in Fourth Year Engineering Mechatronics Through Design Based Learning Curriculum, in M. DeAntonio (Ed.), 2015 IEEE Frontiers in Education Conf. Proc., IEEE, Piscataway, NJ, pp. 2217-2223, 2015.

Chandrasekaran, S., Stojcevski, A., Littlefair, G., and Joordens, M., Learning through Projects in Engineering Education, SEFI 2012: Engineering Education 2020: Meet the Future: Proc. of 40th SEFI Annual Conf., pp. 126-133, 2012.

Froyd, J.E., Wankat, P.C., and Smith, K.A., Five Major Shifts in 100 Years of Engineering Education, Proc. IEEE, vol. 100, pp. 1344-1360, 2012.

Hall, W., Palmer, S., Ferguson, C., and Jones, T., Delivery and Assessment Strategies to Improve On- and Off-Campus Student Performance in Structural Mechanics, Int. J. Mech. Eng. Educ., vol. 35, no. 4, pp. 272-284, 2007.

Hibbeler, R.C., Engineering Mechanics Dynamics, 13th Ed., Prentice Hall, Upper Saddle River, NJ, 2012a.

Hibbeler, R.C., Engineering Mechanics Statics, 13th Ed., Prentice Hall, Upper Saddle River, NJ, 2012b.

Hibbeler, R.C., Mechanics of Materials, 9th Ed., Pearson London, 2013.

Hibbeler, R.C., Statics and Mechanics of Materials, 4th Ed., Pearson London, 2014.

Joordens, M., and Jones, J.T., Multi-disciplinary Design-and-Build Projects in Mechatronic Engineering Degree Courses, Proc. of 11th Australasian Conf. on Engineering Education, Adelaide, pp. 140-145, 1998. 
Krute, L., Keltie, R.F., Lavelle, J.P., Meno, M., and Fortney, W.B., Distance Education Partnerships, Proc. of 2012 American Society for Engineering Education Annual Conf. and Exposition, San Antonio, Session M614, 2012.

Long, J.M., Cavenett, S.W., Gordon, E., and Joordens, M., Enhancing Learning for Distance Students in an Undergraduate Engineering Course through Real-Time WebConferencing, Proc. of 2014 ASEE Int. Forum, Indianapolis, Paper No. 11024, pp. 20.18.1 $-20.18 .11,2014 b$.

Long, J.M., Chandrasekaran, S, and Orwa, J.O., Engineering Fundamentals in a New Undergraduate Curriculum, Smith, S.T., Lim, Y.Y., Bahadori, A., Lake, N., Padilla, R.V., Rose, A., and Doust, K., (eds.), Proc. of 27th Annual Conf. Australasian Assn. for Engineering Education, Southern Cross University, Lismore, Paper No. 5B, 2016.

Long, J.M., Pereira, M., and Chandrasekaran, S., Implementation of Project-Oriented Design-Based Learning in a Second-Year Mechanical/Mechatronics Subject, Huda, N., Inglis, D., Tse, N., and Town, G. (eds.), Proc. of 28th Annual Conf. Australasian Assn. for Engineering Education, Macquarie University, Sydney, pp. 963-973, 2017.

Long, J.M. and Baskaran, K., Engineering Education Down Under: Distance Teaching at Deakin University, Australia, Proc. of 2004 ASEE Annual Conf. Exposition, Salt Lake City, pp. 9.546.1-9.546.12, 2004.

Long, J.M., Joordens, M.A., and Littlefair, G., Engineering Distance Education at Deakin University Australia, Proc. of IACEE 14th World Conf. Continuing Engineering Education, Stanford University, Stanford, CA, Paper No. 113, 2014a.

Maung-Than-Oo, A., Chandran, J., and Stojcevski, A., Technology Adoption in Engineering Design for Distance Education, Int. J. Quality Assurance Eng. Tech. Educ., vol. 3, no. 2, pp. 54-64, 2014.

Moody, J., Distance Education: Why are the Attrition Rates so High? Q. Rev. Distance Educ. vol. 5, no. 3, pp. 205-210, 2004.

New York Times, The Trouble with Online College, The New York Times, p. A22. Accessed from https://www.nytimes.com/2013/02/19/opinion/the-trouble-with-onlinecollege.html, 2013.

Palmer, S., The Performance of a Student Evaluation of Teaching System, Assessment Eval. Higher Educ., vol. 37, no. 8, pp. 975-985, 2012.

Palmer, S. and Bray, S.L., On- and Off-Campus Student Persistence and Academic Performance, Eng. Sci. Educ. J., vol. 11, no. 2, pp. 66-72, 2002.

Pearson Education, Mastering: Engineering and Computer Science. Accessed 2018 December, 23, from https://www.pearsonmylabandmastering.com/northamerica/ masteringengineering/, 2018. 
Phillips, S.M. and Saraniti, M., A Fully Online Accredited Undergraduate Electrical Engineering Program, Proc. of 2016 ASEE Annual Conf. Exposition, New Orleans, 2016. DOI: $10.18260 /$ p.26323

Scott, C.J., Petronella, A., Astatke, Y., and Ladeji-Osias, J.O., Useful Strategies for Implementing an Online Undergraduate Electrical Engineering Program, Proc. of 2012 ASEE Annual Conf. Exposition, San Antonio, pp. 25.1413.1-25.1413.13, 2012.

Tang, W.K., Liu, P.L., Westgate, C.R., and Scalzo, K.A., Online-BSEE (Online Bachelor of Science in Electrical Engineering): A Multi-University Collaboration Project in Partnership with Open SUNY, Proc. of 2015 ASEE Annual Conf. Exposition, Seattle, pp. 26.1204.1 $-26.1204 .10,2015$.

Whiteman, W.E., A Survey of Distance Learning Programs that Offer a Master of Science in Mechanical Engineering Degree, Proc. of 2012 ASEE Annual Conf. Exposition, San Antonio, pp. 25.111.1-25.111.6, 2012. 